\title{
PENALTIES AND LIQUIDATED DAMAGES IN A CHANGING WORLD: RETHINKING THE COMMON LAW POSITION
}

\author{
Oluwadamilola Odetola*
}

\begin{abstract}
Why did Antonio agree to give Shylock a pound of his flesh in the Merchant of Venice? Why was Shylock unable to get his pound of flesh? Parties to a contract are allowed to determine their obligations but cannot freely determine the consequences of breach in the event of nonperformance. Such is the paradox in the law of obligations. Virtually every modern contract contains a liquidated damages clause and common law jurisdictions strive to ensure that such clauses do not offend the rule against penalties. This paper examines the principle of contractual freedom within the narrower context of liquidated damages and penalty clauses. It revisits the principles of the law of penalties as expounded in the classic case of Dunlop Pneumatic Tyre Co. Ltd v. New Garage \& Motor Co. $L t d$, and considers how well they have fared after a century. In making this evaluation, particular attention is paid to English, Australian and Nigerian law. There are issues thrown up by the rigid dichotomy between liquidated damages and penalties and the extent to which commercial partners can negotiate around them. As commercial contracts become more complex and multi-jurisdictional, clarity, certainty and security of transactions have become more fundamental to commercial dealings. This article finds that the dichotomy between penalty and liquidated damages has not only become irrelevant, it also undermines these fundamentals. Arguments made in favour of the dichotomy are self-defeating and confusing. Judicial attempts to bring the penalty rule in consonance with commercial realities also come with problems of their own. Therefore, an abolition of the dichotomy is advocated. This article proposes that in place of the existing unjustifiable paternalistic approach, all agreed

* LL.B (Ibadan), B.L, BCL (Oxon), Law Teacher and Doctoral Researcher at the University of Kent, United Kingdom; and Associate Research Fellow, Institute for Oil, Gas, Energy, Environment and Sustainable Development, Afe Babalola University, Nigeria, email: dodetola@ogeesinstitute.edu.ng.
\end{abstract}


damages should be prima facie valid, subject to clear cases of unequal bargaining power and economic oppression.

Keywords: Penalties; liquidated damages; genuine estimate; commercial justification.

doi: http://dx.doi.org/10.4314/jsdlp.v6i1.11

\section{INTRODUCTION}

$\mathrm{T}$ here is clearly a tension between the fundamental principle that parties are allowed to agree the terms of their contracts within the bounds of the law on the one hand, and the prohibition of penalty clauses in contracts on the other hand. Virtually every form of agreement contains a provision for agreed damages. The common law, however, draws a line between sums calculated and agreed by parties in good faith as a true estimation of loss in the event of default (liquidated damages) and sums intended to coerce the other party's performance or deter them from defaulting (penalties).

In contrast, civil law regimes generally enforce fixed sums, whether they are intended to approximate damages or deter breach. ${ }^{1}$ The common law position on penalties is taken to have been authoritatively expounded in the case of Dunlop Pneumatic Tyre Co. Ltd v. New Garage E Motor Co. Ltd (Dunlop's case). ${ }^{2}$ In that case, the basic principle was laid down that where parties to a contract agree a stipulated sum as damages in the event of breach, the courts would only uphold such amount if indeed it is a genuine pre-estimate. A short examination of the facts of this case is apposite: the appellants, who were manufacturers of motor tyres, covers, and tubes, supplied these goods to the respondents. The respondents bound themselves not to tamper with the marks on the goods, not to sell to any co-operative society at less than the appellants' current list prices and to pay the sum of five pounds by way of liquidated damages for good sold in breach of the agreement. The respondents sold a tyre cover to a co-operative society below the current list price. In an action for

11 Edward Alan Farnsworth, Contracts (4th edn Aspen Treatise Series 2004) s 12.14 .

2 [1915] AC 79, 87-88. 
breach of contract, the court held that the stipulated sum was liquidated damages.

Lord Dunedin succinctly formulated the propositions, which he considered deducible from a wealth of authorities. ${ }^{3}$ His propositions are re-visited in concluding this paper as they form the basis of our conclusion that the dichotomy between penalty and liquidated damages has now lost its value, if it ever had any. The propositions have become difficult to apply to modern commercial dealings and different jurisdictions, including Nigeria, that have felt bound by them for decades now seek more realistic approaches to making sense of the rule. Judges have developed in recent times a new test of "commercial justification" but this test creates other challenges. ${ }^{4}$ For one, it is particularly elusive for an area of law that demands certainty, clarity and security. It is no different from tests of "reasonableness" and "unconscionability" and is, therefore, susceptible to all the arguments that such tests have been subjected to. ${ }^{5}$ One central aim of this paper is to address the problems created by the rule against penalty in commercial contracts. The dichotomy has been rightly described as a historical accident; ${ }^{6}$ moreso because it is selective in application and can be disruptive of legitimate bargains.

This article is in five sections, this introduction being the first. Section 2 gives a historical account of the penalty rule and critically examines the explanations often provided for the dichotomy between penalty and liquidated damages provisions. Section 3 deals with the unsolved puzzle that is the breach limitation. It argues that the stipulation that a penalty clause can only be one triggered by a breach produces illogical and inconsistent results that, arguably, have no place in the modern law of contract. We examine how attempts by the Australian High Court to avoid the undesirable results created by the breach limitation falls into a similar kind of mischief as they try to prevent. Section 4 aggregates

3 Kemble v Farren [1896] 6 Bing 141; Lord Elphinstone v. Monkland Iron and Coal Co [1886] 13 R (HL) 98; Clydebank Engineering and ship building co Ltd $\checkmark$ Don Jose Castaneda [1905] AC 6.

4 Lorna Richardson, "Commercial justification for penalty clauses: the death of the old dichotomy?” (2015) Edinburgh Law Review 119

5 Wayne Courtney, "Reasonableness in contractual decision-making" (2015) LQR 552.

6 Peter Benjamin, "Penalties, Liquidated Damages and Penal Clauses in Commercial Contracts: A Comparative Study of English and Continental Law” (1960) 9 Int'l \& Comp. L.Q. 600, 605. 
arguments about the continued relevance of the dichotomy between penalty and liquidated damages. This involves critical analysis of Lord Dunedin's propositions in Dunlop's case. Section 5 concludes that an abolition of the dichotomy is the best approach for reconciling commercial realities with the common law in this area.

\section{THE PENALTY RULE: RATIONALE}

Many reasons account for the common law distinction drawn between liquidated damages and penalties. The history of relief against penalties under the common law has been traced (although not without some disagreement) to the relief given by the courts against penal bonds. ${ }^{7}$ Penal bonds contained a promise to pay a certain sum of money but where a specified obligation is met, the promise becomes void. Such bonds are now rarely ever used in their historical form but this paper discusses how contractual parties have created modern variants of the penal bond. Prominent scholars like Peter Birks have also attempted to explain the rationale of the rule as an attempt to protect parties from the systematically optimistic nature of humans regarding the future. ${ }^{8}$ A nature that would make them agree to be bound by excessive penalty clauses that they cannot or do not intend to honour. They do this because they are so confident that they can meet their obligations under the contract - very much like Shylock's pound of flesh in The Merchant of Venice. ${ }^{9}$

This explanation suffers from severe over-inclusiveness. It fails to tell us why we do not attempt to protect parties from this innate optimism under the general law. Why would we specifically apply such reasoning to penalty clauses? Furthermore, we could argue that parties agree to be bound by penalties because they bank on judicial intervention to obtain relief from these obligations. The effect of this would be that they enter into agreements which they have no intention of honouring. Whether such parties are deserving of the law's protection is debatable. ${ }^{10}$

$7 \quad$ Wall v Rederiaktiebolaget Lugude [1915] 3 K.B. 66, 72-3.

8 See Downes, "Rethinking Penalty Clauses" in Wrongs \& Remedies in the TwentyFirst Century (Peter Birks ed, Clarendon Press; Oxford 1996) 249; Chen-Wishart, "Controlling the Power to Agree Damages" in Wrongs \& Remedies in the TwentyFirst Century (Peter Birks ed, Clarendon Press; Oxford 1996) 271.

9 Act 1 Scene III of Williams Shakespeare's Merchant of Venice.

10 See N McBride, "A Case for Awarding Punitive Damages in Response to Deliberate Breaches of Contract” (1995) Anglo-American L Rev 369. 
A better rationale for the rule against penalties is that penalties oust the jurisdiction of the court to determine the damages payable by the defaulting party. There are guiding principles for making this determination and rather than fulfil the compensatory aim of damages, ${ }^{11}$ penalties seek to terrorise and punish. Unlike cases of tort, punishment has never been the goal in the law of contract. There is a deep-seated reluctance to view the breach of a contract as a morally reprehensible conduct deserving of punishment under the common law. ${ }^{12}$ This is the same idea that underlies the absence of a general duty of good faith in English contract law. ${ }^{13}$

In defence of liquidated damages, a genuine pre-estimate of loss is considered to fulfil this compensatory aim and, therefore, acceptable. For this reason, it is taken to adopt the courts' method assessment thereby saving judicial time and avoiding the risk of inaccurate assessment. Driving this argument to its logical conclusion will suggest that the liquidated sum must always be identical to what the court would have awarded using the usual principles. We will, however, discover in section 2.1 below that liquidated damages are not free from controversy in this regard.

\subsection{Recoverable Losses}

There are certain losses that are not recoverable under the general law of damages. Principles such as mitigation, remoteness and contributory negligence limits the amount of damages that the court may award to the non-defaulting party. ${ }^{14}$ It is, however, not clear if and how parties in their determination of liquidated damages can factor in these issues. This is because liquidated damages are pre-determined and, as Lord Dunedin emphasized in Dunlop's case, the relevant time is the time of contracting. ${ }^{15}$ Thus, even though liquidated damages may be a genuine attempt by parties to pre-estimate loss, there is a real possibility that the sum bears no

11 Liquidated damages are considered to fulfil this aim because they seek to compensate for loss by making a genuine estimate.

12 Andrew M. Tettenborn, "Punitive Damages for Breach of Contract: What's so Special About Contract Claims” (2005) available at SSRN <http://ssrn.com/ abstract $=938700>$ accessed 22 July 2015.

13 It is interesting to note that this historical position of the concept of good faith has been challenged in recent times. See Justice Leggatt in Yam Seng Pte Limited $v$ International Trade Corp Ltd [2013] EWHC 111 (QB).

14 Adam Kramer, The Law of Contract Damages (Hart Publishing 2014).

15 Dunlop's case (n 2) 86. 
resemblance to what the court, if left to decide, would have awarded as damages. This is as a result of the application of limiting factors such as mitigation, remoteness and contributory negligence. The question then becomes whether it is an acceptable result for the courts to enforce liquidated damages clauses even though such sums would ordinarily have been subject to these limiting factors. Whether this may be considered an acceptable result or not would depend on the perceived utility of limiting factors in contract law.

Remoteness is an established principle, which protects a defaulting party from bearing losses that are unforeseeable, uncontemplated or have no direct connection with the breach. ${ }^{16}$ The principle is strictly applied in contract law such that there must be serious possibility of the occurrence of the type of loss for which compensation is being sought. ${ }^{17}$

Mitigation of damages, on the other hand, is based on the idea that the claimant should be efficient after the defendant's breach. He should neither refuse to make efforts to minimize his loss where possible nor go ahead to incur unreasonably high expenses. ${ }^{18}$ The claimant is simply required to act reasonably. Thus, for instance, Lord Hoffmann stated in South Australia Asset Management Corp v. York Montague Ltd "SAAMCO" that "where there is an available market, any additional loss which the buyer suffers through not having immediately bought equivalent goods at the market price is prima facie caused by his own change of mind". ${ }^{19}$

The remoteness principle only comes into play after the breach has occurred and the court has to determine the recoverable loss. This means that parties are unlikely to give this principle much consideration at the time of contracting. The same reasoning applies to the principle of mitigation as by its very nature, mitigation only becomes possible after the breach has occurred.

16 This principle is discussed in The Heron II [1969] 1 A.C. 350. See also M Stiggelbout "Contractual remoteness, 'scope of duty' and intention” [2012] LMCLQ 97; A Robertson, "The Basis of the Remoteness Rule in Contract" (2008) 28 Legal Studies 172; Kramer, “An Agreement-Central Approach to Remoteness and Contract Damages" in Cohen and McKendrick (eds) Comparative Remedies for Breach of Contract (2004).

17 Parsons v Ingham [1978] Q.B. 791.

18 British Westinghouse v Underground Electric Railways [1912] AC 673; The Golden Victory [2007] 2 AC 353.

19 South Australia Asset Management Corp v York Montague Ltd (SAAMCO) [1997] AC 191, 214. 
Thus, the relevant question is whether these losses, which are ordinarily not recoverable because of the principles mentioned above should be given a free pass when the court is dealing with liquidated damages; or whether the court should still go ahead to apply the limiting principles as they would in other cases. It is not clear from the cases what the position of the law is. In the English case of Robophone Facilities Ltd v. Blank, ${ }^{20}$ Lord Diplock expressed the opinion, without clearly deciding, that these restrictions should not apply to liquidated damages. The merit to this position is that if they were to be applied, whatever judicial time and effort is saved by upholding a liquidated damages clause will be lost in the process of trying to apply these limitations.

Burrows proposed a selective approach. He argues that while the principle of remoteness may be circumvented, the courts should always apply the principle of mitigation to liquidated damages. ${ }^{21}$ This he considers vital in promoting efficiency and discouraging waste by parties. ${ }^{22}$ There may be some justification for this proposition. It is agreed that contracting parties should not be allowed to act unreasonably to the detriment of the other party after the breach has occurred. On the whole, the dichotomy between penalties and liquidated damages could be easily rendered redundant by the application of these limiting factors to all agreed damages. The result of this would be that damages would more often than not consistently reflect the recoverable losses of the parties. Application of the remoteness principle to a penalty clause, for instance, will inadvertently result in a reduction of the sum to better reflect loss that bears a closer connection to the breach.

Notably, the English Law Commission expressed a contrary view and provisionally stated that these two limitations should be applied to liquidated damages. ${ }^{23}$ While the controversy surrounding recoverable losses does not directly impact on the central debate in this paper, it is the writer's view that limiting factors should not be applied to agreed damages clauses in whatever form. This is in line with the principle of certainty in commercial contracts, which this article strongly advocates.

20 (1966) 1 W.L.R 1428, 1447- 8.

21 Andrew Burrows, Remedies for Torts and Breach of Contract (3rd edn, OUP 2004) 442.

22 ibid.

23 Law commission Working Paper, Penalty Clauses and Forfeiture of Monies Paid, No. 61 (1975) para. 15. <www.bailii.org/ew/other/EWLC/1975/c61.pdf> accessed 6 October 2015. 


\subsection{Actual Loss Versus Agreed Damages}

Another issue worth considering is the possibility of variations between the agreed damages and the actual loss. Where a claimant's loss is in fact greater than a penalty, is it open to such claimant to say that the sum is not enforceable because it is a penalty and so should be struck down by the court? The House of Lords left this question open in Cellulose Acetate Silk Co Ltd $v$ Widnes Foundry. ${ }^{24}$ There are different ways of viewing this problem. One is to say that the relevant period is when the contract was made. The penalty clause being invalid at that time should still be held invalid even if it turns out to be advantageous to the defaulting party. Another view is that the reason penalty clauses are held invalid in the first place is to prevent unfairness to the defaulter. Where there is however no such injustice, there is no reason why a penalty clause should not be upheld. Hudson ${ }^{25}$ persuasively argues in support of this viewpoint by pointing out that where the claimant's loss is greater than liquidated damages, he is confined to the liquidated sum so to allow him to recover more where the loss is greater than the penalty treats a claimant (who has acted wrongly by inserting a penalty clause) better than one who has put in a genuine pre-estimate. This is yet another avoidable confusion created by the liquidated damages/penalty dichotomy.

\section{THE BREACH LIMITATION: DISTINCTION WITHOUT A DIIFFERENCE?}

The present position of the law is that a sum can only be struck down as an invalid penalty if triggered by breach. ${ }^{26}$ Consequently, relief against penalty is only applicable where the sum is payable on a breach of contract. If the sum is payable upon any other event such as termination in accordance with the terms of the contract, it is not open to the court to declare the sum a penalty. The problem here is that the distinction between money payable on a breach event and that payable on a non-breach event could be more apparent than real. Parties can by creative drafting make what is in essence a penalty look more like an agreed sum, or a bonus for early completion thereby producing a different outcome and circumventing the law.

24 [1925] Ltd [1933] AC 20.

25 A.H. Hudson, "Penalties Limiting Damages" (1985) 101 L.Q.R. 480.

26 Burrows (n 21) 446. 
The question then becomes more of how well one is able to make an appropriate formulation of the contractual terms rather than what the substantive effect of the clause is. Lord Denning expressed strong dissatisfaction with this state of affairs in Campbell Discount Co. Ltd v. Bridge $e^{27}$ where a stipulated sum was payable in the event of breach or lawful termination. The hirer of a car under a hire-purchase agreement with a finance company, having made an initial payment equal to $£ 105$, paid one monthly instalment on the total hire-purchase price of $£ 482: 10$ s., and then informed the company in writing that he could not keep up the payments and returned the car to them. Clause 6 of the agreement provided that: "The hirer may at any time terminate the hiring by giving notice of termination in writing to the owners, and thereupon the provisions of clause 9 shall apply." Clause 9 provided that, if the agreement was for any reason terminated before the vehicle became the hirer's property, the hirer was to pay such further sums as may be necessary to make the rentals paid and payable equal to two-thirds of the hire-purchase price. The court held, on the basis that the hirer did not exercise his option under clause 6 but was in breach of his obligations, that the amount alleged due under clause 9 was not a genuine pre-estimate of damages, but a penalty. The owner could not therefore rely on clause 9 .

The curious thing about this decision is that it seems to suggest that if the contract had been terminated under clause 6 , the courts would have upheld the sum, the difference lying squarely in the mode of termination. Although Lord Devlin pointed out that clause 9 could not be a sham (as it was) for one purpose and genuine for another, Lords Morton, Radcliffe and Viscount Simonds all agreed that the hirer did not exercise his option under clause 6 (in the absence of breach) and further suggested that the hirer would not have been entitled to relief had that been the case.

Lord Denning disagreed with this outcome. In his words, "The courts have power to grant relief against the sum contained in "minimum payment" clauses, no matter for what reason the hiring is terminated. To act otherwise would mean that equity commits itself to an absurd paradox, it will grant relief to a man who breaks his contract but will penalise the man who keeps it”. ${ }^{28}$

There is a lot of merit in Lord Denning's famous observation in this case, it seems very incongruous that the party in breach is granted relief

27 [1962] AC 600.

28 Bridge's case (n 27) 629. 
while a party that terminates the contract in line with the contract is left worse off, no matter that the sum was indeed excessive. Edwin Peel ${ }^{29}$ also recognizes this unwelcome result: that the payer may be in a better position if he breaches the contract (so that relief may be granted) than if he lawfully exercises an option under the contract which requires the same payment to be made, without scope for any relief. ${ }^{30}$ For Burrows, Lord Denning's approach is commendable because the rationale for imposing sums payable on an event other than breach is not so different from the purpose served by the penalty clause. ${ }^{31} \mathrm{It}$ is either to pre-estimate loss caused by the event or to preclude the claimant from pursuing the event. Drawing a distinction between the two, therefore, seems pointless.

The English Law Commission lent support to Lord Denning's approach by recommending that the court should be able to deal with such clauses in the same way, whether or not they come into operation by breach. ${ }^{32}$ It is interesting to see how this issue has been addressed in Nigeria. In the case of Oyeneyin $v$ Akinkugbe, ${ }^{33}$ Adekeye JSC of the Supreme Court of Nigeria stated that penalty clauses are sanctions which are imposed "in the event of allowing a situation that could be prevented from happening”. With this blanket definition, it is not clear that Nigerian courts are strictly bound by the breach limitation. This is because there may be other events, which are not necessarily breach events, that fall under this wide categorization of "things that could have been prevented". His Lordship went further to state that in enforcing a penalty clause in a contract, one has to consider the special circumstances of the particular case. $^{34}$

The counter argument to this position is that given the intrusion of the penalty rule into the fundamental concept of contractual freedom, it is not sensible to extend it unnecessarily. Unnecessary because there is no liability to pay damages for an event that does not amount to a breach, the stipulated sum does not, therefore, oust the compensatory aim of damages. ${ }^{35}$ The problem with accepting the recommendation of the Law

29 Edwin Peel, “The Rule against Penalties” (2013) LQR 152, 155.

30 ibid.

31 Burrows (n 21) 445.

32 Law com. No 61 (n 23) para. 22.

33 (2010) 4 NWLR (pt 1184) 265 SC.

34 ibid 292.

35 This argument is particularly strong if we accept that the courts upholding the judicial compensatory aim is one of the reasons why relief is granted for penalty clauses. 
Commission and other similar views is that it may be akin to an acceptance of a wider proposition that the court has a general jurisdiction to rewrite contracts when they consider the terms harsh or disadvantageous to either of the parties. ${ }^{36}$ Jurisprudential experience would reveal that couching principles in such wide and general terms often results in arbitrary results. There have been suggestions on how to limit the scope of these powers and they are considered in section 3.1 below.

Traditionally, sums payable upon the occurrence of non-breach events have been treated like an agreed sum.There may have been some confusion as to the nature of the liquidated damages and the similarities they share with the remedy of the award of an agreed sum. ${ }^{37}$ One of such similarities is that they are both common law remedies. There is, indeed, a fundamental difference, which justifies a completely different analysis of the two remedies. An action for an award of an agreed sum is one for the contract price ${ }^{38}$ rather than damages for breach. ${ }^{39}$ Liquidated damages, on the other hand, are an agreed remedy for breach of contract. The liquidated damages/penalty analysis simply does not apply to debt claims. So, in Jervis $v$. Harris, ${ }^{40}$ a lessee covenanted to maintain the demised premises in good tenantable condition and the lease authorized the landlord to enter the premises to view the state of repair.

In default, the landlord could do the work and recover the costs and expenses from the tenant. It was held that where a lease provided by specific covenants for repairs to be carried out by the lessee in default of which the lessor was entitled on notice to enter the property and carry out repairs at the lessee's expense, a claim by the lessor to recover moneys expended in making good a want of repair arising from the lessee's breach of the repairing covenant was a claim for debt and not a claim for damages for breach of covenant. The doctrine of penalties did not apply to a claim in debt. Nigerian courts have also drawn this distinction. In G.M.O.N v. Akputa, ${ }^{41}$ the Supreme Court stated that a line must be drawn between a liquidated demand for a specific debt sum and liquidated damages. It was held that when the amount in question is ascertained or capable of being

36 Law com. No 61 (n 23) para. 41.

37 See Alder $v$ Moore [1961] 2 QB 57.

38 In this sense, it rightly belongs to the group of primary remedies such as specific performance.

39 White E Carter (Councils) Ltd v McGregor [1962] AC 413.

40 [1996] Ch 195.

41 (2010) 9 NWLR (pt 1200) 443 SC. 
ascertained without further investigation, it is a liquidated sum which is distinguishable from damages stipulated by parties as payable on breach.

\subsection{Primary, Collateral and Alternative Stipulations: Lessons from Australia}

The limitation of relief against penalties triggered by breach events is firmly established under the common law. The general acceptance of this principle is what makes the judgment of the High Court of Australia in Andrews v. Australia and New Zealand Banking Group Ltd, ${ }^{42}$ something of a lesson in legal history. The court opined in that case that there is no basis for the proposition that the courts' power to grant relief against a penalty is limited to sums payable as a consequence of the breach of a contractual obligation. The factual background of the case is interesting and of universal appeal. It is connected to the validity of bank charges imposed on bank customers who have exceeded the authorised limit on borrowing. ${ }^{43}$ The issue of excessive bank charges has raised a lot of dust in many jurisdictions. Nigeria is not exempted from the dissatisfaction of consumers with the different charges imposed by banks but unfortunately and unlike in Australia and England, there has not been active judicial and legislative ${ }^{44}$ response.

The opposition to extortionate bank charges under common law has been on the ground that the sums are penalties as they do not represent a genuine pre-estimate of the bank's loss, and that they are unconscionable and arbitrary. The judicial approach has however been to apply the breach limitation in these cases. Thus, in Office of Fair Trading $v$. Abbey National $P l c,{ }^{45}$ Andrew Smith J., at first instance, found that that no breach was committed by a customer who exceeded the authorized borrowing limit and therefore relief against penalty did not apply. This has remained the position of the law for long time. ${ }^{46}$

42 [2012] HCA 30.

43 This case has English equivalents such as decision of the Supreme Court in Office of Fair Trading v Abbey National Plc [2009] UKSC 6; [2010] 1 A.C. 696.

44 In Australia, the Fair Trading Act 1999 (Vic), the Consumer Credit (Victoria) Code, and the National Credit Code; in England, under the Unfair Terms in Consumer Contracts Regulations (1999).

45 [2008] EWHC 875 (Comm); [2008] 2 All E.R. (Comm) 625.

46 See Euro London Appointments Ltd $v$ Claessens International Ltd [2006] EWCA Civ 385; [2006] 2 Lloyd's Rep. 437; MEJ Polymers Ltd $v$ Imerys Minerals Ltd [2008] EWHC 344; [2008] 1 Lloyd's Rep. 541; General Trading Company (Holdings) Ltd v Richmond Corporation Ltd [2008] EWHC 1479 (Comm); [2008] 2 Lloyd's Rep. 475. 
The High Court of Australia in Andrews v. Australia and New Zealand Banking Group Ltd, therefore, stands apart in its declaration that there is no basis for the distinction between breach and non-breach events. It has been mentioned that the skilled draftsman all too easily evades the breach limitation. Using Peel's example, D promises to construct a building for $£ 1$ million; if he promises to complete by January 1,2014 , and agrees to pay $£ 50,000$ for each month by which he is late. Such payment may be challenged as a penalty; if he makes no promise about the time of completion, but the parties agree that he shall be paid £1 million for completion on or before January 1 , or $£ 950,000$ for completion after January 1 but before February 1, or $£ 900,000$ for completion after February 1 but before March 1, and so on. There is no scope for the rule to apply because there is no breach by way of late completion. ${ }^{47}$

While many judicial pronouncements and commentaries have criticized the breach limitation and the unacceptable results it could yield, one must recognize that there is some utility to be derived from the breach limitation; it helps to set important boundaries without which the width and depth of the penalty rule will be unknown. As the Law Commission puts it, it should not be the case that every price payable under a contract should be subject to judicial control. ${ }^{48}$ This problem of boundaries is what the Andrews case ultimately seeks to address and what the case is truly remarkable for. The case pushes forward the idea of primary, alternative and collateral stipulations. Rather than ask whether the sum is payable on breach or not, the relevant question becomes whether as a matter of construction, the parties have structured their bargain in the form of primary and collateral stipulations, or in the form of alternative stipulations. ${ }^{49}$

The recommendation of the Australian High court is to limit the rule against penalties to those stipulations which can be identified as collateral to, and security for, the satisfaction of a primary stipulation while alternative stipulations are to be upheld by the courts. ${ }^{50}$ This echoes the suggestions of Lord MacDermott CJ in Lombank Ltd $v$. Kenned ${ }^{51}$ that the essential question is whether the relevant stipulation is calculated to secure performance. ${ }^{52}$

47 Peel (n 29) 155; Law com. No 61 (n 23) para. 18.

48 Law com. No 61 (n 23) para. 22.

49 Mason, 'Notes on Andrews v ANZ [2012] HCA 30' [2013] LMCLQ 233.

50 Andrews (n 42) 10; Peel (n 29) 155.

51 [1961) N.I 192, 207.

52 The Law Commission also makes a similar proposal, Law com. No 61 (n 23) para. 69. 
One can immediately see the issues that the collateral/alternative stipulation approach breeds. Firstly, it merely replaces the breach/nonbreach analysis with a different kind of analysis - one which is just as susceptible to avoidance by clever draftsmanship. Secondly, the distinction between an obligation, which is collateral to a primary obligation and one that is an alternative, is not always easy to draw. Two examples illustrate this point: (a) In exchange for a motorbike, A promises B that he will clean B's windows on Monday or, failing that pay B 500, 000; (b) In exchange for a motorbike, A promises B that he will pay B 500,000, or in the alternative clean B's windows on Monday. In (a), the obligation to pay 500,000 is clearly collateral to the window cleaning while in (b) it is an alternative stipulation. ${ }^{53}$ Thirdly, there is a strong tendency that the "substance over form" principle of equity will be watered down if the courts do not take special care in applying this principle.

Using the illustration, it is clear that the two clauses only differ in form but their effects are essentially the same. In both clauses, the obligation to pay 500,000 is still excessive and there is no clear reason why a party should be able to get away with it just because it is couched in alternative rather than collateral form. The case of Interfoto Picture Library Ltd v. Stiletto Visual Programmes $L t d^{54}$ offers itself to this sort of analysis. The plaintiffs ran a photographic transparency lending library. Following a telephone inquiry by the defendants, the plaintiffs delivered to them 47 transparencies together with a delivery note containing nine printed conditions. Condition 2 stipulated that all the transparencies had to be returned within 14 days of delivery otherwise a holding fee of $£ 5$ a day and value added tax would be charged for each transparency retained thereafter. The defendants, who had not used the plaintiffs' services before, did not read the conditions and returned the transparencies four weeks later whereupon the plaintiffs invoiced the defendants for $£ 3,783.50$. The defendants refused to pay and the plaintiffs brought an action to recover that sum. It was held that where clauses incorporated into a contract contained a particularly onerous or unusual condition, the party seeking to enforce that condition had to show that it had been brought fairly and reasonably to the attention of the other party.

Following the reasoning in Andrews' case and assuming the condition had been brought to the claimant's attention, it would have been open to

53 ibid para. 18.

54 [1988] QB 433. 
the claimant in Interfoto to claim that the sum was intended as an alternative to returning the transparencies within the given time frame (i.e., return by one date with no charge, or return at a later date with a charge). Banks will also be able to get away with excessively high charges by maintaining that the customer had merely been given the alternative of staying within the borrowing limit without charge or exceeding it with a charge.

\section{SHOULD PENALTY CLAUSES BE UPHELD? DUNLOP PNEMATIC TYRES THROUGH THE YEARS}

We have so far taken a critical look at some of the issues thrown up by the common law rule on penalties. Notably, the breach limitation creates unfair results in commercial contracts and attempts to get around it have only resulted in further confusion. It seems apt to commence this section with an examination of Lord Dunedin's propositions in Dunlop's case with the aim of probing if they continue to be good law for modern-day contracts.

\subsection{Sum in Terrorem Versus Genuine Pre-Estimate of Damage}

The difficulty with Lord Dunedin's proposition that "the essence of a penalty is a payment of money stipulated as in terrorem of the offending party and the essence of liquidated damages is a genuine covenanted preestimate of damage" is that it assumes that if a sum is not a genuine preestimate, then its essence must necessarily be to terrorize the other party into compliance. While this assumption is understandably a reflection of the common law aversion to punishment in contract law, we must now answer the question whether it is necessarily true and if so, whether this is so great a mischief that must be prevented by the law. As far back as 1961, The English Law Commission commenting on this proposition stated that it gives little guidance because contract law itself has a coercive force, so it is not uncommon to find cases where the defendant feels bound to perform a contract he would have preferred to break because of the fear of damages. ${ }^{55}$ Furthermore, the sum (which this proposition assumes is automatically a penalty because it is not a genuine pre-estimate) may actually be less than actual loss suffered.

Conversely, liquidated damages may exceed the amount of actual

55 Law com. No 61 (n 23) para. 8, 34. 
loss and this fact may be known to the defendant before a breach occurs, leading to the result that he is acting in terrorem despite the "genuineness" of the estimate. ${ }^{56}$ Hence, Lord Radcliffe's speech in Bridge's case that there are penalties where the defendant is not in terrorem but they still deserve the protection of the courts nonetheless. ${ }^{57}$ It is the writer's argument that this simplistic distinction is no basis for the special protection that the law seeks to give to parties with equal bargaining power who make consensual commitments and stipulate the consequences for breach.

Another important point to note is that since the case of Pneumatic Tyres was decided, the notion of penalties has now been extended beyond money payments. Thus, in Jobson $v$. Johnson, ${ }^{58}$ relief against penalty was extended to a clause to transfer shares.

\subsection{Extravagant and Unconscionable Amount in Comparison with the Greatest Loss Conceivable from the Breach}

This is one of the tests proposed in Dunlop's case. It is clear from this proposition that the principle of remoteness has some place in the common law of penalties. There is some support for this position in Philip Hong Kong v. AG of Hong Kong ${ }^{59}$ where the Privy Council stated: “... It is also acceptable to take account of the fact that the actual loss was not greater than the agreed damages even though the matter should be judged as at the contract date, what actually happened can provide valuable evidence as to what could have been reasonably expected to be the loss at the time the contract was made". Also, in the Nigerian case of Edem Archibong v. Ephraim Duke, ${ }^{60} \mathrm{Weber} J$ admitted that although a genuine pre-estimate may be difficult to make at the time of contracting, it is reasonable for parties to attempt to provide for liquidated damages as long as it is not so disproportionate to a reasonable estimate. ${ }^{61}$ Much has been said about the application of limiting factors to liquidated damages and will not be repeated here.

56 ibid.

57 Bridge's case (n 27).

58 [1989] 1 WLR 1026.

59 (1993) 61 BLR 41.

60 [1923] IV. N.L.R. 92.

61 A similar approach is taken in South Africa; Conventional Penalties Act 1962, s 3. 


\subsection{Sum Greater than the Sum, which Ought to Have Been Paid Under Contract}

Lord Dunedin interestingly commented on this test that, "whether it had its historical origin in the doctrine of the common law. That when $A$ promised to pay $B$ a sum of money on a certain day and did not do so, $B$ could only recover the sum with, in certain cases, interest, but could never recover further damages for non-timeous payment, or whether it was a survival of the time when equity reformed unconscionable bargains merely because they were unconscionable, is probably more interesting than material". ${ }^{62}$ The passage of time and the increased complexity of commercial agreements have however revealed that it is indeed material. There is a tension, if not an inconsistency, between this test and the modern approach to interests. ${ }^{63}$

In the case of loans, increases in the rate of interest payable following breach have been closely scrutinized. In Lordsvale Finance Ltd v. Bank of $\mathrm{Zambia}^{64}$ where the loan agreements provided for an additional, but unexplained, 1 per cent increase in interest in the event of default, the court held that (i) there was no reason in principle why a contractual provision should be struck down as a penalty if the increase could in the circumstances be explained as commercially justifiable, provided its dominant purpose was not to deter the other party from breach; and (ii) that the rate of 1 per cent could not be said to be in terrorem but was consistent only with an increase in the consideration for the loan by reason of the increased credit risk represented by a borrower in default.

\subsection{Single Lump Sum on the Occurrence of One or More or All of Several Events}

The argument has been made that this is about what happens when a single sum is payable on termination (calculated in terms of loss of bargain damages) and the contract may be terminated for a minor or major breach. ${ }^{65}$ This creates a tension between the proposition as expounded by Lord Dunedin and what is commercially obtainable. In the Dunlop case itself, this presumption was rebutted because although there were

62 Dunlop's case (n 2) 87, 88.

63 Peden \& Carter, “Agreed Damages Clauses - Back to the future?” (2006) 22 JCL 189.

64 [1996] QB 752.

65 Peden \& Carter (n 63) 195. 
several ways in which tyres could be sold or offered in breach of the agreement the loss likely to result from any such breach was difficult to assess and $£ 5$ represented a genuine attempt to do so. Indeed, the relevant question should be whether there has been a termination resulting in loss and not the weight of the breach. On the other hand, it is no obstacle to the sum stipulated being a genuine pre-estimate of damage, that the consequences of the breach are such as to make precise pre-estimation almost impossible. On the contrary, that is just the situation when it is probable that pre-estimated damage was the true bargain between the parties. ${ }^{66}$

His Lordship mentioned that it is just one of those cases where it seems quite reasonable for parties to contract that they should estimate that damage at a certain figure, and provided that figure is not extravagant there would seem no reason to suspect that it is not truly a bargain to assess damages, but rather a penalty to be held in terrorem. Even though this test can be criticized for being vague and of little help to the courts when faced with the less straightforward cases, it can be said to have laid the foundation for flexibility now observed in more complex and sophisticated agreements. Thus, in Philips Hong Kong, ${ }^{67}$ the Privy Council upheld a clause in a road construction contract as a liquidated damages clause. Lord Woolf considered that "the courts should not be too zealous in knocking down clauses as penal. And that what parties have agreed should normally be upheld ... otherwise, it would render it so difficult to draw up valid liquidated damages clause in complex commercial contracts". One can now see the principle of commercial justifiability, necessity and reasonableness taking centre stage in more recent cases.

There is generally a reluctance of the courts to interfere in commercial agreements, which are genuinely made for reasonable commercial purpose and necessitated by commercial realities, without just cause. This reluctance is not only observable in relation to penalty clauses and liquidated damages. A very recent instance is the English case of Arnold v. Britton, ${ }^{68}$ where the courts refused to deviate from the clear intention of the lease in question despite the fact that it produced a ridiculously unfair burden on the tenants. The president of the English Supreme Court, Lord Neuberger closed his judgment in that case by stating: "there are

66 Dunlop's case (n 2) 86.

67 Philip (n 59).

68 (2015) UKSC 36. 
various statutory provisions which protect tenants against unreasonable service charges, but none of them apply here ... there may be a strong case for extending such provisions but that is a policy issue for parliament." ${ }^{69}$ Where there is an applicable legislation or not, it becomes more difficult to justify an intervention when the parties are considered to be of equal commercial standing and knowledge.

The treatment of exemption clauses further illustrates this shift in reasoning. With the enactment of the Unfair Contract Terms Act 1977 (and very recently the English Consumers Right Act 2015), judge-made restrictions to exemption clauses have gradually fallen away. ${ }^{70}$ More recent cases have therefore paid attention to factors such as commercial knowledge of the parties and understanding of how markets work. ${ }^{71}$ This recognition of the fact that judges are not commercial persons and should not undermine the security of transactions by trying to rewrite the bargains of commercial parties is valuable.

The gradual pre-eminence of this notion of commercial justifiability in penalty cases can be glimpsed from other cases like Lordsvale v. Bank of $\mathrm{Zambia}^{72}$ considered above. In MEJ Polymers Ltd $v$. Imerys Minerals $L t d,{ }^{73}$ the court in upholding a take or pay (minimum payment) clause stated that it was commercially justifiable, did not amount to oppression, was negotiated and freely entered into between parties of comparable bargaining power, and did not have the predominant purpose of deterring a breach of contract nor amount to a provision in terrorem. The court decided that the take or pay provision did not offend the rule against penalties and the claimant was entitled to recover the price of the shortfall.

In the very recent decision of the English Court of Appeal in Makdessi $v$ Cavendish, ${ }^{74}$ The court conceded that older authorities had approached the issue as a dichotomy between a genuine pre-estimate of loss on the one hand, and a penalty on the other. However, more recent authorities show the courts adopting a broader test of whether a clause was extravagant and unconscionable with a predominant function of

69 ibid 65.

70 See Elizabeth MacDonald \& Ruth Atkins, Koffman's Law of Contract (8th ed, OUP 2014) Ch 10.

71 See Allen Fabrications Limited $v$ ASD Limited [2012] EWHC 2213; cf Hollier v Rambler Motors (AMC) Ltd [1971] EWCA Civ 12.

72 Lordsvale (n 64).

73 [2008] EWHC 344.

74 [2013] EWCA Civ 1539. 
deterrence and declining to consider it unenforceable where there was a commercial justification. ${ }^{75}$ The major test for determining the predominant purpose (whether commercial necessity or deterrence) is the question of proportion. Where the sum is all out of proportion then it is open to the court to conclude that the sum went beyond compensation and into the territory of deterrence. It is interesting that the Australian courts are increasingly making constant reference to conscionability and good faith as the real basis for the penalty rule. ${ }^{76}$

Recent Nigerian authorities confirm that the principles laid down by Lord Dunedin in Dunlop's case still hold sway in Nigeria and the evolving trend in common law jurisprudence which focuses on commercial justification and predominant purpose has not been a great deal of attention by Nigerian courts. ${ }^{77}$ The case of GChitex Industries v. Oceanic Bank Intl, ${ }^{78}$ however, stands out. Although the main point for decision in that case was remoteness of damages, Belgore JSC regarded reasonability as the major factor in distinguishing between arbitrary and genuine estimation of damages. ${ }^{79}$ While this suggests a move in a more flexible direction, there is a need to move the law beyond the grey area of "reasonableness" in this regard. In light of the fact that Nigeria is currently experiencing a boom in foreign investment and there is a surge in novel and sophisticated cross-border transactions, this is an important consideration. Agreed damages clauses and their validity become extremely important in cross-border transactions because parties are understandably nervous to leave damage assessment courts of unfamiliar territories.

Considering the issues that have been raised in the preceding sections of this work, it is doubtful that the continued distinction between penalties and liquidated damages is sustainable, at least in its original formulation. Nonetheless, we are reluctant to admit of a new formulation as the solution to the problems. This is because the rule has become unnecessary and

75 This case comes before the Supreme Court in the summer of 2015, it will be interesting to see if the Supreme Court will decisively endorse a more flexible approach to the rule against penalties, especially in relation to commercial and consumer contracts.

76 See Ringrow Pty Ltd v BP Australia Pty Ltd [2005] HCA 71, (2005) 224 CLR 656.

77 N.A.C.B Ltd v Achagwa (2010) 11 NWLR (pt 1205) 339 C.A; G.M.O.N \& S Co Ltd v Akputa (2010) 9 NWLR (pt 1200) 443 SC; Oyeneyin v Akinkugbe (2010) 4 NWLR (pt 1184) 265 SC.

78 CLRN 11 (2005) at 12.

79 ibid 18. 
there is more to be gained from its abolition than restatement in any manner. ${ }^{80}$ As seen above, the dichotomy between penalties and liquidated damages by Lord Dunedin using the idea of in terrorem is quite slender. Commercial entities strive to navigate around penalty clauses. ${ }^{81}$ One of the strongest arguments for liquidated damages is that it reduces the likelihood of serious dispute between parties and saves time which is often a precious, valuable commodity in business. ${ }^{82}$ However, it may be argued that whatever time is saved by the recognition of agreed damages by the courts is quickly lost in the process of making a determination (especially in sophisticated and highly technical contracts) as to whether the sum is indeed a penalty or liquidated damages.$^{83}$ Our discussions here show that this determination is almost never a straight forward one. It has become increasingly riddled with gimmicks, manoeuvres and unsolved puzzles.

Persons in the anti-penalty school of thought, on the other hand, are regarded as substantially unfair and inefficient as it makes parties stick to uneconomical contracts. ${ }^{84}$ In answer to this, Burrows rightly notes that the efficient breach theories ignore the possibility of bargaining around a penalty clause. ${ }^{85}$ This happens quite often in commercial transactions, as parties are wary of commencing lengthy and expensive litigation. It has also been argued that penalties may incentivize a claimant to induce breach. ${ }^{86}$ This point is readily deflated by the fact that this is only likely to happen when the penalty is higher than the actual loss, which is not always the case. Another anti-penalty argument is that punishment belongs to criminal and not civil law; however, experience with the law of torts shows that this is not completely true. ${ }^{87}$

80 Jonathan Morgan, Great Debates in Contract Law (Palgrave Macmillan 2012).

81 There are so many clauses that are upheld as a matter of practice by courts that are in effect penalties. One of them, deposits, is discussed later in this work.

82 This point of view is particularly championed by efficient breach theorists: Richard Posner, Economic Analysis of Law (New York: Little Brown and Co. 1973); Stephen A Smith, Contract Theory (Oxford University Press 2004) Ch 11.2. For an opposing view, see Friedmann, "The Efficient Breach Fallacy” (1989) 18 JLS 1.

83 Chares J. Goetz and Robert E. Scott, "Liquidated Damages, Penalties and the Just Compensation Principle: Some Notes on an Enforcement Model and a Theory of Efficient Breach” (1977) 77 Colum. L. Rev. 554, 560-61.

84 ibid.

85 Burrows (n 21) Ch. 20

86 K.W Clarkson, R. Miller and T.J Muris, 'Liquidated Damages V. Penalties: Sense or Nonsense?' (1978) Wisconsin L. Rev 351, 353.

87 The award of punitive damages in torts provides an apt illustration. See Rookes $v$ Barnard (1964) A.C 1129; Robert Stevens, Torts and Rights (OUP 2007). 
The case for upholding penalty clauses rests on the protection of the principle of the freedom of contract. It is suggested that agreed damages clauses should be prima facie valid subject to vitiating factors such as undue influence and misrepresentation. This will encourage contract making, ensure certainty and reduce litigation costs. Also, with the initiation of protective legislations such as the Unfair Contract Terms Act ${ }^{88}$ the danger which that the penalties rule seems so eager to curb may be exaggerated. Another argument for abandoning the dichotomy is that the law is arbitrarily selective in its application.

The legal treatment of forfeiture of monies paid deserves some attention here. It is clear that one of the purposes of such deposits is to secure complete performance of the payer's obligations under the contract, yet the courts will normally uphold the forfeiture clause except in some rare cases where relief against forfeiture is granted..$^{89}$ The difference between forfeiture and penalty clauses seem merely cosmetic, i.e., deposits are paid in advance while penalties are payable only on breach, after the contract has come to an end. The effect of both payments are however similar. A forfeiture clause can also be regarded as imposed in terrorem and worse still, the payee can sue for damages in spite of the forfeiture. Regarding the sale of land, for instance, the common law as a matter of practice allows a 10 per cent deposit and would uphold its forfeiture. ${ }^{90}$ This sum seems arbitrary and there is no basis to show that it is a genuine estimate of loss.

From theoretical, historical and practical perspectives, the common law of liquidated damages and penalties leaves us with many unanswered questions; it is unclear what the courts ought to do with the limiting factors like mitigation and remoteness, what the reaction of the courts should be when actual loss suffered is greater than the so called penalty and whether courts should stick to the breach limitation despite the unpleasant results it yields. Clearly, it is becoming more difficult to justify the incursion into the freedom of contract that the dichotomy demands. This is especially true for commercial contracts between equal parties that have competent advisers. Commercial contracts in reality often

88 The Nigerian Consumer Contracts (Unfair Terms) Bill 2010 demonstrates an attempt to offer similar protection from certain oppressive contractual terms as is done in other jurisdictions such as England (the Unfair Contracts Act 1977, 1999).

89 Stockloser v Johnson [1954] 1 QB 476.

90 Workers Trust and Merchant Bank Ltd v Dojap Investments Ltd [1993] AC 573. 
involve series of negotiations between parties, knowledgeable legal and financial advisers will likely conduct risk assessments and tear every clause apart before the parties finalize a deal.

The major function of agreed damages is the avoidance of dispute and ease of compensation for non-performance. Additionally, it could also serve as security against non-performance. Whether commercial parties decide to construct their agreed damages clause to perform the function of compensation or they build a collateral element into it to protect their bargains should not call for judicial intervention. What is important is that the clause represents the legitimate intention of the parties. The courts hardly interfere in other legitimate contractual attempts by parties to insulate themselves against the risk of non-performance and we argue that agreed damages clauses should be no different. The reason why commercial parties agree damages in their contracts is to avoid a third party assessment of what they consider adequate compensation for breach. This is to save time and also achieve the legitimate expectations of the parties from their agreements.

The commercial justification test is perhaps a better test because it focuses on achieving commercially sensible outcomes. It is agreed that two responsible judges can hold opposing views on what is commercially justifiable in different situations. This becomes even more difficult as contracts become more complex, multi-layered and multi-jurisdictional. It is albeit an easier path to thread than attempting to assess damages in such situations. However, what may be more efficient is to remove the blanket rule against penalties where equal commercial parties are concerned and reserve the commercial justification test for cases of extreme unreasonableness.

Most of the arguments in this work focus on commercial entities with equal bargaining power but we do not deny that there are deserving cases for intervention. A case may be made for situations where there is no such equality. Contracts between big corporations and consumers who have little or no room for bargaining will fall within this exception. This is not a novel proposition, as consumer welfarism has informed legislation in some jurisdictions thereby limiting protection to those who really need it. $^{91}$

91 The English Unfair Contract Terms Act1977, the Unfair Terms in Consumer Contracts Regulations 1999 ( this is based on an EU Regulation which is in force in the member countries of the EU) and the Consumer Acts Right 2015. 
While the common law world awaits specific legislation on penalty and liquidated damages, the courts would do well to treat equal parties as equal in this area. If the law is to display true commitment to the performance of obligations, especially those made between parties of equal bargaining power and sophistication, the rule against penalties must become an exception and not the rule. Continued application of the penalty rule to contracts between commercial parties will only be a case of one giant using the law as a weapon to bully his way out of a legitimate and binding promise to another. And as Olatawura JSC stated in the case of Kusfa v. United Bawo Construction Co, ${ }^{92}$ the law should not assist parties to break their contracts with impunity.

\section{CONCLUSION}

This article has engaged in a critical analysis of the common law dichotomy between penalties and liquidated damages. The basic propositions laid down in Dunlop's case have undergone severe modifications in today's commercial world. The dichotomy remains, but the lines have become ever blurry and confusing. Out of commercial necessity, courts have shifted focus to questions of commercial justification, reasonableness and fairness. This article has addressed how these evolving tests also create problems of their own. The liquidated damages/penalty rule is not only unnecessary in commercial contracts, it is problematic. This article has raised the difficult questions: Are commercial parties really terrorized by the prospect of paying penalties? Are they really entitled to enlist the court's protection when they are called upon to make good on their promises?

Legislation designed to protect consumers and parties susceptible to economic oppression can render the rule against penalty redundant, as a general rule. But beyond that, the rule may breed more confusion than it did in the past as courts strive to achieve commercially sensible results by applying a commercial justification test. This article strongly advocates an abandonment of the common law dichotomy between penalties and liquidates damages in commercial contexts. In many jurisdictions, legislative reform has been used to modify the common law of contract

92 [1994] 4 NWLR (pt. 336) 1. 
such that specific protection is given to those who need it. ${ }^{93}$

It is doubtful that the matter will soon be resolved in such a decisive manner under Nigerian law as contract law is typically not an area dealt with by legislative action. ${ }^{94}$ However, it is not unthinkable that Nigerian judges (despite being faithful to long standing principles of common law) also show commitment to achieving commercially sensible results. This is evident in some of the cases considered in this article, which show an inclination towards the commercial justification test. At this point, a surgical break from the hold of the age-old dichotomy may not be on the front burner of Nigerian law reform. However, with the exponential increase in multijurisdictional commercial transactions, financial innovations and complex contractual arrangements, there is reason to believe that this change may come sooner than later. Passage of the Unfair Contract Terms Bill 2010 into law and anticipated legislative reform in other jurisdictions are factors that are likely to influence the pace of reform in this area.

93 S1 (1) of the Penalty Clauses (Scotland) Bill available at <www.scotland.gov.uk/ Publications/2010/07/penalty-clauses $>$ accessed 7 October 2015. The Scottish Government consulted on the draft bill in July 2010 and the Scottish Law Commission believes there is merit in further reform. See $<$ www.scotlawcom.gov.uk/law-reform-projects/contract-law-in-light-of-thedraft-common-frame-of-reference-dcf/>accessed 7 October 2015; The US Uniform Commercial Code also provides a platform for extensive reform to contract law in the United States; Interestingly, The English Law Commission in 1975 mentioned the enforcement of both liquidated damages and penalties as one of the possible reform steps but quickly ruled out this possibility without an explanation. It is perhaps as a result of the reluctance to unsettle deeply rooted principles of common law. However, recent decisions in the UK would suggest movement in a different direction.

94 Note that there is a (Consumer) Unfair Contract Terms Bill 2010 which has not been passed into law. 